\title{
Rendimento e composição química do capim-braquiária introduzido em pastagem degradada de capim-gordura ${ }^{1}$
}

\author{
Cláudio Manoel Teixeira Vitor ${ }^{2 *}$, Dilermando Miranda da Fonseca ${ }^{3}$, Luciano de Melo \\ Moreira $^{2}$, Jailson Lara Fagundes ${ }^{2}$, Domicio do Nascimento Júnior ${ }^{3}$, José Ivo Ribeiro Júnior ${ }^{4}$, \\ André Leite Pereira ${ }^{5}$
}

\footnotetext{
1 Projeto financiado pela CAPES.

2 Programa de Pós-graduação em Zootecnia - UFV, MG.

${ }^{3}$ Departamento de Zootecnia da UFV, MG.

${ }^{4}$ Departamento de Informática da UFV, MG.

${ }^{5}$ Curso de Graduação em Zootecnia - UFV, MG.
}

RESUMO - Um experimento foi conduzido para avaliação de uma pastagem de capim-gordura (Melinis minutiflora, Beauv.) degradada, renovada por meio da introdução de capim-braquiária (Brachiaria decumbens, Stapf) em consórcio com estilosantes (Stylosanthes guianensis, cv. Mineirão) e da adubação com nitrogênio (0, 50, 100 e 150 kg/ha.ano). O delineamento experimental foi de blocos ao acaso com três repetições. A pastagem foi avaliada em um período seco com um único corte e em um período chuvoso com três cortes. A adubação nitrogenada aumentou a produção de massa seca (MS) e o teor de proteína bruta (PB) do capim-braquiária, tanto no período seco quanto no chuvoso. Os teores de fibra em detergente neutro (FDN) e de fibra em detergente ácido (FDA) não foram influenciados pelas doses de nitrogênio em nenhum dos períodos avaliados. Nas maiores doses de nitrogênio, os teores de fósforo, cálcio e magnésio não se alteraram no período seco nem no chuvoso, enquanto os teores de potássio diminuíram em ambos os períodos. A produção de MS no consórcio de capim-braquiária com o estilosantes foi similar à obtida com o capim-braquiária sem adubação nitrogenada no período seco e não diferiu estatisticamente da produção observada com adubação nitrogenada no período chuvoso. Em geral, o teor de proteína bruta da forragem do consórcio foi maior que o da gramínea pura adubada com nitrogênio.

Palavras-chave: adubação nitrogenada, consórcio gramínea-leguminosa, fibra, minerais, proteína, Zona da Mata Mineira

\section{Yield and chemical-proximal composition of signalgrass established on a degraded molassesgrass pasture}

\begin{abstract}
An experiment was carried out to evaluate the reclamation of a degraded pasture of molassesgrass (Melinis minutiflora, Beauv.), with the establishment of signalgrass (Brachiaria decumbens, Stapf), with different $\mathrm{N}$ doses $(0,50,100$, and $150 \mathrm{~kg} / \mathrm{ha}$.year) or in consortium with $S$. guianensis cv. mineirão, in a complete randomized blocks design, with three replications per treatment. Evaluations were performed during the dry season (one evaluation) and wet season (three evaluations). Nitrogen fertilization promoted increment in dry matter production and crude protein (CP) concentration of signalgrass, in both seasons. There were no effect of neutral detergent fiber and acid detergent fiber concentration of signalgrass in both seasons. Increasing $\mathrm{N}$ doses did not alter $\mathrm{P}, \mathrm{Ca}$, and $\mathrm{Mg}$ concentration neither in the dry nor in the rainy seasons, but it decreased $\mathrm{K}$ concentration in both seasons. Signalgrass and Stylosanthes mixture presented low dry matter production in the dry season, being similar to signalgrass without nitrogen fertilizer. During the wet season, however there was no statistical difference between the consortium and treatments with nitrogen fertilization. The consortium, in general, presented greater forage CP concentration compared to signalgrass fertilized with nitrogen.
\end{abstract}

Key Words: consortium grass-legume, fiber, minerals, nitrogen fertilization, protein, "Zona da Mata Mineira"

\section{Introdução}

A Zona da Mata de Minas Gerais possui pastagens localizadas geralmente emáreas de topografia acidentada, combaixa fertilidade natural. O capim-gordura (Melinis minutiflora) é a gramínea predominante na maioria dessas pastagens e vem sendo substituído gradativamente por gramíneas mais competitivas, como as do gênero Brachiaria (Botrel et al., 1994).

Este artigo foi recebido em 22/5/2006 e aprovado em 28/5/2008

Correspondências devem ser enviadas para claudiomanoel@epamig.br.

* Endereço atual: EPAMIG - CTNM, Rodovia MGT 155, km 122, CEP: 39525-000, Nova Porteirinha, MG. 
O manejo inadequado e as deficiências nutricionais do solo têm promovido a redução da produtividade do capimgordura nos locais onde essa substituição ainda não ocorreu, bem como nas pastagens de capim-braquiária, resultando no aparecimento de áreas descobertas, povoadas por invasoras de folhas largas ou por gramíneas de baixo valor nutritivo, levando à degradação das pastagens.

A recuperação e/ou a renovação de pastagens são estratégias para melhoria da produção e cobertura vegetal em áreas degradadas. Entende-se por recuperação o restabelecimento da capacidade produtiva da pastagem formada com a mesma espécie, utilizando-se ou não a semeadura (Rodrigues \& Reis, 1994). A renovação da pastagem, por sua vez, consiste na utilização de práticas agronômicas visando à completa substituição da forrageira existente na pastagem por outras.

Na renovação de pastagem, é fundamental a escolha da espécie forrageira a ser utilizada. O capim-braquiária (Brachiaria decumbens), por proporcionar ótima cobertura do solo, mesmo em regiões montanhosas, e possibilitar elevado ganho por animal, além de uma capacidade de suporte relativamente alta em relação a outras gramíneas, tem sido recomendado para a Zona da Mata Mineira (Botrel \& Xavier, 2000).

Uma prática de manejo de pastagem que tem proporcionado aumento na capacidade de suporte animal na propriedade e melhoria no desempenho econômico é o uso de fertilizantes, sobretudo o nitrogenado (Jarvis, 1998), que aumenta a produção e a qualidade da forragem (Paciullo et al., 1998; Ribeiro et al., 1999; Andrade et al., 2003). Com o aumento do nível de nitrogênio no solo, a planta forrageira suporta maior freqüência de utilização (Costa \& Saibro, 1984), aumentando a produção de massa seca, a taxa de lotação e o ganho de peso animal (Favoretto et al., 1985). Entretanto, o nitrogênio tem custo elevado e pode ser facilmente perdido quando não associado à parte orgânica do solo.

Nesse sentido, a introdução de leguminosas nas pastagens é uma forma de se buscar maior economicidade na produção de forragem para os animais criados em condições de campo, quando comparada ao uso de pastagens de gramíneas exclusivas. A principal expectativa do seu uso em pastagem é a melhoria e diversificação da dieta do animal, assim como o aumento da massa de forragem pelo aporte de nitrogênio ao sistema, por intermédio de sua reciclagem e transferência para a gramínea acompanhante (Pereira, 2001).

O gênero Stylosanthes, sobretudo o Stylosanthes guianensis, o Stylosanthes capitata e o Stylosanthes macrocephala, tem boa adaptação a solos de baixa fertilidade e maior número de recomendações para o ecossistema cerrado, como o Stylosanthes guianensis cv. Mineirão lançado pela EMBRAPA (Barcellos et al., 2000).

Assim, realizou-se este trabalho para avaliar a renovação de uma pastagem degradada de capim-gordura na Zona da Mata de Minas Gerais com a introdução de capim-braquiária adubado com nitrogênio e cultivado em consórcio com estilosantes.

\section{Material e Métodos}

O experimento foi conduzido na Universidade Federal de Viçosa, em área do Departamento de Zootecnia, durante o período de março de 2000 a maio de 2001. Viçosa está localizada na Zona da Mata Mineira, em uma altitude de $651 \mathrm{~m}, 20^{\circ} 45^{\prime}$ de latitude sul e $42^{\circ} 51^{\prime}$ de longitude oeste. Durante o período experimental, registrou-se temperatura média anual de $19^{\circ} \mathrm{C}$, com média das máximas e mínimas de 22,1 e $15^{\circ} \mathrm{C}$. A umidade relativa do ar foi, em média, de $80 \%$ e a precipitação anual, de 1.340 mm (Estação Meteorológica da UFV), com estações seca e chuvosa bem definidas. O clima da região, pelo sistema de Köppen (1948), é classificado como Cwa, subtropical, com inverno ameno e seco.

A pesquisa foi desenvolvida em uma área de pastagem de capim-gordura (Melinis minutiflora, Beauv.) degradada, renovada com capim-braquiária (Brachiaria decumbens, Stapf), onde foram avaliadas quatro doses de adubo nitrogenado (0, 50, 100 e $150 \mathrm{~kg} / \mathrm{ha}$.ano) e o consórcio de capim-braquiária com a leguminosa estilosantes (Stylosanthes guianensis, cv. Mineirão). O delineamento utilizado foi em blocos completamente casualizados, com três repetições.

Antes da implantação do experimento, avaliaram-se a cobertura do solo e a distribuição da vegetação na área experimental com base na metodologia descrita por Mannetje \& Haydock (1963). Foram alocados 90 quadrados de 0,5 m de lado na área experimental para avaliação do grau de degradação pela estimativa visual. Os resultados revelaram que a área apresentava 10\% de capim-gordura, 12\% de capim-sapé (Imperata brasiliensis Trin.), 7\% de outras forrageiras, $5 \%$ de outras daninhas e $66 \%$ sem nenhuma vegetação. Nesta mesma época, foram retiradas amostras de solo na área experimental, na camada de 0 a $20 \mathrm{~cm}$ de profundidade, para análises físico-químicas (Tabela 1). O solo foi classificado como Latossolo Vermelho-Amarelo distrófico (LVAd), de textura argilosa.

Para facilitar a operação de abertura dos sulcos, realizou-se a queima controlada na área experimental visando à eliminação da vegetação existente. Na abertura dos sulcos, 
Tabela 1 - Características químicas e físicas da amostra superficial $(0$ a $20 \mathrm{~cm})$ do solo estudado

\begin{tabular}{|c|c|}
\hline Característica & Resultado \\
\hline \multicolumn{2}{|l|}{ Química } \\
\hline $\mathrm{pH}\left(\mathrm{H}_{2} \mathrm{O}, 1: 2,5\right)$ & 5,00 \\
\hline $\mathrm{P}-\mathrm{mg} / \mathrm{dm}^{3}$ & 2,40 \\
\hline $\mathrm{K}-\mathrm{mg} / \mathrm{dm}^{3}$ & 44,00 \\
\hline $\mathrm{Na}-\mathrm{mg} / \mathrm{dm}^{3}$ & 7,00 \\
\hline Ca - cmolc $/ \mathrm{dm}^{3}$ & 0,50 \\
\hline $\mathrm{Mg}-\mathrm{cmolc} / \mathrm{dm}^{3}$ & 0,20 \\
\hline $\mathrm{Al}-\mathrm{cmolc} / \mathrm{dm}^{3}$ & 0,70 \\
\hline $\mathrm{H}+\mathrm{Al}-\mathrm{cmolc} / \mathrm{dm}^{3}$ & 6,70 \\
\hline Soma de bases - cmolc/ $\mathrm{dm}^{3}$ & 0,84 \\
\hline CTC efetiva - cmolc/ $\mathrm{dm}^{3}$ & 1,54 \\
\hline CTC a pH $7-\mathrm{cmolc} / \mathrm{dm}^{3}$ & 7,57 \\
\hline Saturação de bases - \% & 11,40 \\
\hline Saturação de Al - \% & 43,70 \\
\hline $\mathrm{Zn}-\mathrm{mg} / \mathrm{dm}^{3}$ & 2,15 \\
\hline $\mathrm{Fe}-\mathrm{mg} / \mathrm{dm}^{3}$ & 123,00 \\
\hline $\mathrm{Mn}-\mathrm{mg} / \mathrm{dm}^{3}$ & 15,50 \\
\hline $\mathrm{Cu}-\mathrm{mg} / \mathrm{dm}^{3}$ & 2,45 \\
\hline \multicolumn{2}{|l|}{ Física } \\
\hline Areia grossa - dag/kg & 17,00 \\
\hline Areia fina - dag/kg & 16,00 \\
\hline Silte - dag $/ \mathrm{kg}$ & 14,00 \\
\hline Argila - dag $/ \mathrm{kg}$ & 53,00 \\
\hline
\end{tabular}

utilizou-se um sulcador reversível tracionado por uma junta de bois deixando os sulcos espaçados $1 \mathrm{~m}$ e com profundidade de 15 a $20 \mathrm{~cm}$.

A correção do solo foi realizada com aplicação de calcário dolomítico (PRNT 100\%), a lanço, espalhado uniformemente em toda a área experimental, na dose de 1,7 t/ha, correspondente à metade da dose recomendada para o caso de incorporação do corretivo na camada de 0 a $20 \mathrm{~cm}$ de profundidade do solo. Foram aplicados ainda $450 \mathrm{~kg} / \mathrm{ha}$ de superfosfato simples, adicionados manualmente no fundo do sulco, no momento da semeadura das espécies, de acordo com os tratamentos, utilizando-se sementes puras viáveis de capim-braquiária (4 kg/ha) e estilosantes ( 2 kg/ha ). Nas parcelas $(10 \times 10 \mathrm{~m})$ correspondentes à consorciação do capim-braquiária com o estilosantes, a gramínea foi semeada em sulcos alternados com o da leguminosa.

De outubro de 1998 até março de 2000, a área experimental foi utilizada para o desenvolvimento de projeto de pesquisa de Moreira (2000). A partir desta data, efetuou-se corte de uniformização de todas as plantas na área experimental e iniciaram-se as avaliações desta pesquisa, considerando duas fases, denominadas época seca e época chuvosa.

Na época seca, de março a agosto de 2000, foi realizada adubação potássica ( $60 \mathrm{~kg} / \mathrm{ha}$ de $\mathrm{K}_{2} \mathrm{O}$ ) na forma de cloreto de potássio, fosfatada (45 kg/ha de $\mathrm{P}_{2} \mathrm{O}_{5}$ ), na forma de superfosfato simples, e nitrogenada, utilizando-se uréia, parcelada em duas aplicações, em março e maio de 2000, sempre em dias com alguma precipitação. Não foi aplicado adubo nitrogenado nas áreas com estilosantes.

Para avaliar a massa de forragem nas parcelas, em agosto de 2000, foi alocado um quadro de 2,0 $\times 0,5 \mathrm{~m}\left(1 \mathrm{~m}^{2}\right)$, por três vezes dentro de cada parcela, e toda a forragem existente dentro deste quadro foi colhida (a $15 \mathrm{~cm}$ do solo, exceto o estilosantes, que foi a $25 \mathrm{~cm}$ ) e pesada, retirando-se uma amostra representativa para secagem durante 48 horas em estufa a $65^{\circ} \mathrm{C}$. As plantas foram separadas nos seguintes grupos: capim-braquiária, estilosantes, capim-gordura, capimsapé, outras daninhas e outras forrageiras. As produções de matéria seca, em kg/ha, do capim-braquiária e do estilosantes no consórcio foram somadas para obtenção da produção total da parcela e comparação à produção do consórcio com a produção da gramínea exclusiva, cujo valor foi quantificado de acordo com a produção individual da gramínea. Nas cinco doses de nitrogênio testadas, prevaleceram os valores individuais encontrados para cada característica avaliada no capim-gordura, no capim-sapé, em outras daninhas e outras forrageiras existentes e identificadas.

Na época chuvosa, de setembro de 2000 a maio de 2001, foram aplicadas as mesmas doses de adubo fosfatado, potássico e nitrogenado da época seca, porém, nesta época, todos os nutrientes foram parcelados em duas aplicações (setembro de 2000 e março de 2001). Mais uma vez, não foi aplicado adubo nitrogenado nas áreas com estilosantes. Foram realizadas três amostragens de forragem para a avaliação neste período: dezembro de 2000, março de 2001 e maio de 2001. A produção de matéria seca $(\mathrm{kg} / \mathrm{ha})$ das espécies existentes na área experimental correspondeu ao somatório das três datas de amostragem.

As análises para determinação dos teores de proteína bruta (PB) foram feitas conforme metodologia descrita por Silva (1990) e as de FDN e FDA, segundo o método descrito por Van Soest (1965). Para determinação dos teores de P, K, Ca e Mg na forragem, as amostras foram mineralizadas por via úmida ( $4 \mathrm{~mL} \mathrm{HNO}_{3}$ concentrado e $1 \mathrm{~mL} \mathrm{HClO}_{4}$ 70-72\% para $0,2 \mathrm{~g}$ de MS) e as soluções resultantes, devidamente diluídas, foram analisadas para determinação dos teores de fósforo, por colorimetria, $\mathrm{K}$, por fotometria de chama, e de Ca e Mg, por espectrofotômetro de absorção atômica.

As análises estatísticas dos dados foram realizadas com auxílio do programa SAEG. As características avaliadas foram submetidas à análise de variância e posterior análise de regressão para estudo dos efeitos do nitrogênio na gramínea, adotando-se o modelo com coeficiente de regressão significativo a 5 ou 1\% de significância pelo teste t. Para avaliar a gramínea em cada dose de nitrogênio, as médias foram comparadas pelo teste F, adotando-se o nível de 
significância de $5 \%$. O consórcio foi comparado à gramínea exclusiva com doses de nitrogênio aplicando-se o teste de Dunnet a 5\% de probabilidade.

\section{Resultado e Discussão}

No período seco, a produção de massa seca (MS) do capim-braquiária aumentou linearmente $(\mathrm{P}<0,01)$ em resposta às doses de nitrogênio, enquanto as outras espécies existentes na área não foram influenciadas $(\mathrm{P}>0,05)$ pela adubação nitrogenada (Tabela 2). A ausência de resposta ao nitrogênio provavelmente foi ocasionada pela competição do capim-braquiária, que reduziu o desenvolvimento dessas invasoras. As produções de MS do capim-braquiária foram inferiores às encontradas por Botrel et al. (1994) para a dose de nitrogênio de $50 \mathrm{~kg} / \mathrm{ha}$, o que poderia ser atribuído à falta de preparo total do solo neste trabalho em comparação à pesquisa de Botrel et al. (1994), na qual a aração e gradagem proporcionaram melhores condições iniciais para o desenvolvimento das plantas.

No período chuvoso, a produção de forragem do capim-braquiária nas doses de nitrogênio aplicadas ajustou-se a um modelo quadrático $(\mathrm{P}<0,05)$, com produção máxima de $14.478 \mathrm{~kg} / \mathrm{ha}$ de MS na dose de nitrogênio estimada de $88,75 \mathrm{~kg} /$ ha (Tabela 2). Essa resposta quadrática, entre outros fatores, pode ter sido ocasionada pela deficiência de outros nutrientes, provavelmente potássio $\left(44,0 \mathrm{mg} / \mathrm{dm}^{3}\right)$ e fósforo $\left(2,40 \mathrm{mg} / \mathrm{dm}^{3}\right)$, uma vez que, em geral, esta gramínea responde a doses de nitrogênio maiores que $150 \mathrm{~kg} / \mathrm{ha}$. Contudo, esses valores de produção de MS do capimbraquiária foram superiores aos encontrados por Botrel et al. (1994) para a mesma gramínea, no período chuvoso, na dose de nitrogênio de $50 \mathrm{~kg} / \mathrm{ha}$. Essa alta produção de MS do capim-braquiária neste estudo indica boa adaptação e boa resposta ao nitrogênio aplicado na região da Zona da Mata Mineira.

Não foi observada relação $(\mathrm{P}>0,05)$ entre a produção de MS e as doses de nitrogênio para o capim-gordura e para as daninhas (Tabela 2). No capim-sapé, a produção de MS diminuiu $(\mathrm{P}<0,05)$ linearmente (Tabela 2$)$ até a dose estimada de nitrogênio de $126,72 \mathrm{~kg} / \mathrm{ha}$, na qual a produção estabilizou em 49,77 kg/ha de MS. O crescimento dessa invasora, segundo Cruz Filho et al. (1986), é reduzido, em razão de seu baixo potencial de resposta à fertilização, e da menor competição com o capim-braquiária. As outras forrageiras, no entanto, aumentaram linearmente $(\mathrm{P}<0,05)$ a produção de MS com a aplicação de nitrogênio dentro da parcela com capim-braquiária. Este aumento de produção das outras forrageiras pode ter contribuído para elevar a competição pelo nitrogênio aplicado e diminuir a produção do capim-braquiária a partir da dose de nitrogênio de $100 \mathrm{~kg} / \mathrm{ha}$.

No consórcio de capim-braquiária e estilosantes, a produção de MS obtida foi de $1.018 \mathrm{~kg} / \mathrm{ha}$ (Tabela 3), a participação da gramínea foi de 68,13\% (694 kg/ha) e a da leguminosa, de 31,87\% (324 kg/ha) no período seco. A produção do consórcio foi inferior $(\mathrm{P}<0,05)$ à obtida com adubação nitrogenada nas doses de 50, 100 e 150 kg/ha, mas não diferiu $(\mathrm{P}>0,05)$ entre o consórcio e o capim-braquiária sem adubação nitrogenada (Tabela 3). Esse resultado pode indicar que a distância entre os sulcos $(1 \mathrm{~m})$ promoveu redução dos resíduos vegetais do estilosantes para reciclagem, que, segundo Cantarutti \& Boodey (1997), é a forma mais eficiente de transferência do nitrogênio da leguminosa para a gramínea. Entretanto, resultado diferente foi encontrado por Cadish et al. (1989) em um ecossistema com estação seca bem definida nas associações gramínealeguminosa, onde a leguminosa participava com 30 a 50\% do total de forragem disponível, a fixação de nitrogênio foi entre 50 e $100 \mathrm{~kg} / \mathrm{ha}$.ano. Portanto, a quantidade fixada de nitrogênio depende do desenvolvimento e da distribuição da leguminosa na área, da fertilidade do solo, dos efeitos climáticos e da quantidade de resíduos da leguminosa reciclados (Alves \& Medeiros, 1997).

$\mathrm{Na}$ época seca, não foi observada diferença $(\mathrm{P}>0,05)$ entre a produção de matéria seca (kg/ha) do capim-gordura,

Tabela 2 - Produções de matéria seca (MS - kg/ha) das espécies avaliadas nas áreas com capim-braquiária adubadas com nitrogênio nas épocas seca e chuvosa

\begin{tabular}{lccccc}
\hline Espécie & \multicolumn{2}{c}{ Época seca } & & Época chuvosa \\
\cline { 2 - 3 } & Equação & $\mathrm{R}^{2}$ & & Equação \\
\hline Capim-braquiária & $\hat{\mathrm{Y}}=1.424,12+13,8824^{* *} \mathrm{~N}$ & 0,79 & & $\hat{\mathrm{Y}}=8.995,50+123,544^{*} \mathrm{~N}-0,696^{*} \mathrm{~N}^{2}$ & 0,99 \\
Capim-gordura & $\hat{\mathrm{Y}}=96,68$ & & $\hat{\mathrm{Y}}=260,73$ & - \\
Capim-sapé & $\hat{\mathrm{Y}}=94,51$ & & $\hat{\mathrm{Y}}=904,05-6,597^{*} \mathrm{~N}$ & 0,93 \\
Daninhas & $\hat{\mathrm{Y}}=23,5$ & - & $\hat{\mathrm{Y}}=356,51$ & - \\
Outras forrageiras & $\hat{\mathrm{Y}}=360,06$ & - & $\hat{\mathrm{Y}}=108,34+48,3924^{*} \mathrm{~N}$ & 0,98 \\
\hline
\end{tabular}

* $\mathrm{e}^{* *}$ Significativo a 5 e $1 \%$ de probabilidade pelo teste $\mathrm{t}$, respectivamente. 
Tabela 3 - Produção de matéria seca $(\mathrm{kg} / \mathrm{ha}$ ) do capim-braquiária, do capim-gordura, do capim-sapé, de daninhas e de outras forrageiras adubadas com nitrogênio e dos consórcios com estilosantes nos períodos seco e chuvoso

\begin{tabular}{|c|c|c|c|c|c|}
\hline & Capim-braquiária & Capim-gordura & Capim-sapé & Daninhas & Outras forrageiras \\
\hline \multicolumn{6}{|l|}{ Época seca } \\
\hline$B+E^{1}$ & $1.018 \mathrm{~b}$ & $65 a$ & $164 a$ & $70 a$ & $56 a$ \\
\hline $\mathrm{B}+50 \mathrm{~N}$ & $2.184 \mathrm{a}$ & $153 a$ & $139 a$ & $21 \mathrm{a}$ & $37 \mathrm{a}$ \\
\hline $\mathrm{B}+100 \mathrm{~N}$ & $3.430 \mathrm{a}$ & $110 a$ & $79 a$ & $28 \mathrm{a}$ & $400 \mathrm{a}$ \\
\hline$B+150 N$ & $3.073 \mathrm{a}$ & $84 \mathrm{a}$ & $70 a$ & $38 a$ & $998 a$ \\
\hline$B+E$ & $9.237 \mathrm{a}$ & $596 a$ & $875 a$ & $213 a$ & $2.749 \mathrm{a}$ \\
\hline $\mathrm{B}+0 \mathrm{~N}$ & $8.995 a$ & $414,4 \mathrm{a}$ & $945 \mathrm{a}$ & $496 a$ & $446 a$ \\
\hline $\mathrm{B}+50 \mathrm{~N}$ & $13.436 a$ & $234 a$ & $592 \mathrm{a}$ & $191 \mathrm{a}$ & $2.207 \mathrm{a}$ \\
\hline $\mathrm{B}+100 \mathrm{~N}$ & $14.390 \mathrm{a}$ & $367 a$ & $84 a$ & $220 a$ & $4.577 \mathrm{a}$ \\
\hline $\mathrm{B}+150 \mathrm{~N}$ & $11.814 \mathrm{a}$ & $27 a$ & $15 a$ & $519 a$ & $7.721 \mathrm{a}$ \\
\hline
\end{tabular}

${ }_{1}^{1} \mathrm{~B}+\mathrm{E}-$ capim-braquiária e estilosantes em consórcio.

$2 \mathrm{~N}$ - nitrogênio $(\mathrm{kg} / \mathrm{ha})$.

${ }^{3} \mathrm{CV}$ - coeficiente de variação.

Médias das doses de nitrogênio seguidas pela mesma letra da média do consórcio, na coluna, não diferem $(P>0,05)$ entre si pelo teste de Dunnett.

do capim-sapé, de daninhas e de outras forrageiras no consórcio e nas parcelas com adubação nitrogenada. Na época chuvosa, no entanto, no consórcio capim-braquiária e estilosantes, a produção média de MS foi de $9.237 \mathrm{~kg} / \mathrm{ha}$ (Tabela 3), com participação de 69,91\% da gramínea (6.458 kg/ha) e de 30,09\% da leguminosa (2.779 kg/ha). Assim, a proporção entre gramínea e leguminosa no consórcio neste período se manteve semelhante à do período seco. Não foi observada diferença $(P>0,05)$ entre as produções de matéria seca ( $\mathrm{kg} / \mathrm{ha}$ ) do consórcio e as do capim-braquiária, do capim-gordura, do capim-sapé, de daninhas e das outras forrageiras obtidas com adubação nitrogenada, o que indica que houve boa fixação e transferência de nitrogênio para as gramíneas nesse período (Tabela 3).

Observou-se efeito linear $(\mathrm{P}<0,01)$ das doses de nitrogênio nos teores de $\mathrm{PB}$ do capim-braquiária, tanto no período seco quanto no chuvoso (Tabela 4). Resultados semelhantes foram encontrados por Gomide et al. (1984) e Mendes (2000), que verificaram efeito positivo do nitrogênio sobre o teor de proteína em gramíneas. De fato, a adubação nitrogenada em pastagens tropicais eleva o teor de proteína bruta da matéria seca disponível, principalmente em virtude do aumento na quantidade de nitrogênio solúvel nas formas orgânica e inorgânica no solo (Morrison, 1987). Os teores de PB do capim-gordura nas parcelas com capim-braquiária aumentaram linearmente $(\mathrm{P}<0,01)$ com as doses de nitrogênio no período seco (Tabela 4). Carvalho \& Saraiva (1987) também observaram aumento nas concentrações de nitrogênio na parte aérea do capim-gordura conforme elevaram os níveis desse nutriente.
No período chuvoso, não houve participação do capim-gordura nas amostras em quantidade suficiente para realização das análises laboratoriais, por isso, não foram obtidos resultados de PB, FDN, FDA, fósforo, potássio, cálcio e magnésio dessa gramínea.

O teor de PB do consórcio capim-braquiária e estilosantes no período seco foi superior $(\mathrm{P}<0,05)$ ao do capim-braquiária sem adubação nitrogenada, mas não diferiu $(\mathrm{P}>0,05)$ dos teores obtidos com adubação nitrogenada nas doses de 50 e $100 \mathrm{~kg} /$ ha e foi inferior $(\mathrm{P}<0,05)$ ao obtido com adubação nitrogenada na dose de $150 \mathrm{~kg} / \mathrm{ha}$ (Tabela 5). Esses resultados indicam que, no consórcio capim-braquiária e estilosantes, no qual a leguminosa contribuiu com 31,87\% da MS total da parcela, o teor de PB foi equivalente à aplicação de nitrogênio de até $100 \mathrm{~kg} / \mathrm{ha}$ e a aplicação de $150 \mathrm{~kg} / \mathrm{ha}$ foi mais eficiente que o consórcio com estilosantes. Essa menor equivalência da contribuição do estilosantes na dose de nitrogênio de $150 \mathrm{~kg} /$ ha pode ser atribuída ao método de implantação, em sulcos alternados espaçados a $1 \mathrm{~m}$, que não permitiu a completa transferência do nitrogênio fixado para a gramínea.

No período chuvoso, no consórcio capim-braquiária e estilosantes, o teor de $\mathrm{PB}$ não diferiu $(\mathrm{P}>0,05)$ do obtido com o capim-braquiária adubado com nitrogênio (Tabela 5). Nesse caso, apesar de o teor de PB da leguminosa ter sido maior que o da gramínea, a participação da leguminosa foi relativamente baixa (30,09\% da MS total) e insuficiente para promover diferenças nos valores do consórcio. Os teores de PB encontrados no período chuvoso foram superiores aos do período seco, o que confirma a importância da água na absorção de nutrientes pelo solo, sobretudo o nitrogênio. 
Tabela 4 - Concentrações de nutrientes na matéria seca (MS) de gramíneas avaliadas em áreas com capim-braquiária adubadas com nitrogênio nas épocas seca e chuvosa

\begin{tabular}{|c|c|c|c|c|}
\hline & \multicolumn{2}{|l|}{ Época seca } & \multicolumn{2}{|c|}{ Época chuvosa } \\
\hline & Equação & $\mathrm{R}^{2}$ & Equação & $\mathrm{R}^{2}$ \\
\hline PB - capim-braquiária & $\hat{\mathrm{Y}}=3,59+0,0284^{* *} \mathrm{~N}$ & 0,97 & $\hat{\mathrm{Y}}=4,88+0,0508^{* *} \mathrm{~N}$ & 0,99 \\
\hline PB - capim-gordura & $\hat{\mathrm{Y}}=4,38+0,0302^{* *} \mathrm{~N}$ & 0,89 & - & - \\
\hline FDN - capim-braquiária & $\hat{Y}=63,44$ & - & $\hat{\mathrm{Y}}=66,54$ & - \\
\hline FDN - capim-gordura & $\hat{\mathrm{Y}}=23,5$ & - & - & - \\
\hline FDA - capim-braquiária & $\hat{\mathrm{Y}}=31,14$ & - & $\hat{\mathrm{Y}}=35,43$ & - \\
\hline FDA - capim-gordura & $\hat{\mathrm{Y}}=28,18+0,0804^{* *} \mathrm{~N}$ & 0,89 & - & - \\
\hline P - capim-braquiária & $\hat{\mathrm{Y}}=0,1452$ & - & $\hat{\mathrm{Y}}=0,2344$ & - \\
\hline $\mathrm{P}$ - capim-gordura & $\hat{\mathrm{Y}}=0,129+0,000606^{* *} \mathrm{~N}$ & 0,96 & - & - \\
\hline K - capim-braquiária & $\hat{\mathrm{Y}}=1,25-0,00333^{* *} \mathrm{~N}$ & 0,92 & $\hat{\mathrm{Y}}=2,016-0,00571^{*} \mathrm{~N}$ & 0,70 \\
\hline K - capim-gordura & $\hat{\mathrm{Y}}=0,8373+0,00985^{* *} \mathrm{~N}-0,00005275^{* *} \mathrm{~N}^{2}$ & 0,96 & - & - \\
\hline Ca - capim-braquiária & $\hat{\mathrm{Y}}=0,525$ & - & $\hat{\mathrm{Y}}=0,4888$ & - \\
\hline Ca - capim-gordura & $\hat{\mathrm{Y}}=0,342$ & - & - & - \\
\hline Mg - capim-braquiária & $\hat{\mathrm{Y}}=0,257$ & - & $\hat{\mathrm{Y}}=0,1205$ & - \\
\hline Mg - capim-gordura & $\hat{\mathrm{Y}}=0,151$ & - & - & - \\
\hline
\end{tabular}

* ${ }^{* *}$ Significativo a 5 e $1 \%$ de probabilidade pelo teste t, respectivamente.

Tabela 5 - Concentrações (\%) de nutrientes na matéria seca (MS) de gramíneas avaliadas com capim-braquiária adubado com nitrogênio nas épocas seca e chuvosa

\begin{tabular}{|c|c|c|c|c|c|c|}
\hline & \multicolumn{3}{|c|}{ Capim-braquiária } & \multicolumn{3}{|c|}{ Capim-gordura } \\
\hline \multicolumn{7}{|l|}{ Época seca } \\
\hline $\begin{array}{l}B+E^{1} \\
B+0 N^{2} \\
B+50 N \\
B+100 N \\
38,66 a B+150 N \\
C V^{3}(\%)\end{array}$ & $\begin{array}{l}5,95 \mathrm{~b} \\
3,87 \mathrm{a} \\
4,51 \mathrm{~b} \\
6,61 \mathrm{~b} \\
7,90 \mathrm{a} \\
13,99\end{array}$ & $\begin{array}{c}62,23 a \\
61,27 a \\
64,63 a \\
65,97 a \\
61,91 a \\
5,69\end{array}$ & $\begin{array}{c}37,11 \mathrm{a} \\
34,30 \mathrm{a} \\
31,21 \mathrm{a} \\
29,44 \mathrm{a} \\
29,61 \mathrm{a} \\
14,52\end{array}$ & $\begin{array}{c}5,11 \mathrm{~b} \\
4,23 \mathrm{~b} \\
5,83 \mathrm{~b} \\
8,35 \mathrm{a} \\
7,68\end{array}$ & $\begin{array}{c}71,05 \mathrm{~b} \\
68,94 \mathrm{~b} \\
67,59 \mathrm{a} \\
8,38 \mathrm{a} \\
70,17 \mathrm{~b} \\
2,03\end{array}$ & $\begin{array}{c}31,61 \mathrm{a} \\
27,15 \mathrm{a} \\
32,53 \mathrm{a} \\
67,40 \mathrm{a} \\
38,52 \mathrm{a} \\
16,00\end{array}$ \\
\hline \multicolumn{7}{|l|}{ Época chuvosa } \\
\hline $\begin{array}{l}B+E^{1} \\
B+0 N^{2} \\
B+50 N \\
B+100 N \\
B+150 N \\
C V^{3}(\%)\end{array}$ & $\begin{array}{l}7,19 a \\
5,05 a \\
5,94 a \\
7,32 a \\
8,82 a \\
16,68\end{array}$ & $\begin{array}{c}66,47 a \\
68,26 a \\
65,92 a \\
66,15 a \\
65,80 a \\
5,15\end{array}$ & $\begin{array}{c}37,35 a \\
34,74 a \\
33,15 a \\
34,17 a \\
37,93 a \\
8,06\end{array}$ & $\begin{array}{l}- \\
- \\
- \\
- \\
-\end{array}$ & $\begin{array}{l}- \\
- \\
- \\
- \\
-\end{array}$ & $\begin{array}{l}- \\
- \\
- \\
- \\
- \\
-\end{array}$ \\
\hline
\end{tabular}

${ }^{1} \mathrm{~B}+\mathrm{E}$ - capim-braquiária e estilosantes em consórcio.

${ }^{2} \mathrm{~N}$ - nitrogênio $(\mathrm{kg} / \mathrm{ha})$.

${ }^{3} \mathrm{CV}$ - coeficiente de variação.

Médias das doses de $\mathrm{N}$ seguidas pela mesma letra da média do consórcio, na coluna, não diferem $(P>0,05)$ entre si pelo teste de Dunnett.

Os teores de fibra em detergente neutro (FDN) e de fibra em detergente ácido (FDA) do capim-braquiária, tanto no período seco quanto no período chuvoso, não foram influenciados $(\mathrm{P}>0,05)$ pela adubação nitrogenada (Tabela 4). De fato, nos trabalhos em geral, tem ocorrido ausência ou pequena influência da adubação nitrogenada sobre os teores de FDN e FDA na forragem, conforme verificado por Ribeiro et al. (1999), em lâminas de capimelefante cv. Mott, e Alvin et al. (1996), em capim-coastcross. No capim-gordura, também não foi observado efeito $(\mathrm{P}>0,05)$ da adubação nitrogenada sobre o teor de FDN nas parcelas com capim-braquiária no período seco, entretanto, os teores de FDA aumentaram linearmente $(\mathrm{P}<0,01)$ com as doses de nitrogênio. 
No consórcio capim-braquiária e estilosantes, em comparação ao capim-braquiária adubado com nitrogênio, não foi detectada diferença $(\mathrm{P}>0,05)$ entre os teores de FDN nem entre os teores de FDA, tanto no período seco quanto no chuvoso (Tabela 5). Segundo Van Soest (1965), os teores de FDN acima de 55 a $60 \%$ na matéria seca correlacionaram-se negativamente com o consumo de forragem. Neste trabalho, todas as doses de nitrogênio e os consórcios avaliados promoveram valores superiores ao valor crítico máximo, portanto, em condições de pastejo, podem reduzir o consumo voluntário do capim-braquiária.

Os teores de fósforo (P), cálcio (Ca) e magnésio (Mg) no capim-braquiária nos períodos seco e chuvoso não foram influenciados ( $\mathrm{P}>0,05)$ pela adubação nitrogenada (Tabela 4), o que não era esperado, uma vez que o aumento na produção de MS com a adubação nitrogenada geralmente promove efeito de diluição dos outros nutrientes. Os teores de potássio $(\mathrm{K})$ reduziram linearmente $(\mathrm{P}<0,01)$ também nos dois períodos estudados (Tabela 4), o que neste caso pode ser atribuído ao processo natural de diluição do nutriente com o aumento da produção de MS (Ribeiro et al., 1999). Por outro lado, nas áreas com capim-braquiária, o capim-gordura apresentou no período seco relação linear positiva $(\mathrm{P}<0,01)$ entre os teores de fósforo e as doses de nitrogênio, enquanto os teores de potássio apresentaram resposta quadrática $(\mathrm{P}<0,01)$ às doses de nitrogênio, com teores máximos de potássio na dose de nitrogênio de 93,34 kg/ha (Tabela 4).

O teor de cálcio no consórcio capim-braquiária e estilosantes na época seca não diferiu $(\mathrm{P}>0,05)$ do obtido no capim-braquiária adubado com nitrogênio, enquanto o de magnésio no consórcio capim-braquiária e estilosantes foi inferior $(\mathrm{P}<0,05)$ ao do capim-braquiária adubado com nitrogênio nas doses de 50, 100 e $150 \mathrm{~kg} / \mathrm{ha}$ e semelhante $(\mathrm{P}>0,05)$ ao observado sem adubação nitrogenada (Tabela 6). Os teores de fósforo do capim-braquiária foram inferiores $(\mathrm{P}<0,05)$ aos determinados no consórcio com o estilosantes, somente na dose de nitrogênio de $50 \mathrm{~kg} / \mathrm{ha}$. Nas demais doses, os teores de fósforo foram semelhantes $(\mathrm{P}>0,05)$ ao do consórcio (Tabela 6). Esses estão relacionados ao fato de o teor de fósforo no estilosantes $(0,1668 \mathrm{dag} / \mathrm{kg})$ ter sido semelhante ao do capim-braquiária (0,1666 dag/kg), o que alterou muito pouco a média no consórcio. O teor de potássio no consórcio capim-braquiária e estilosantes foi superior $(\mathrm{P}<0,05)$ aos obtidos com todos os outros consórcios com capim-braquiária e adubação nitrogenada (Tabela 6). Como neste consórcio a produção de MS foi inferior à obtida com o capimbraquiária adubado com nitrogênio, os maiores valores podem ser atribuídos ao efeito de concentração de potássio na gramínea, que atingiu 1,6382 dag/kg de MS, enquanto no estilosantes foi de $0,960 \mathrm{dag} / \mathrm{kg}$. A participação de matéria seca do capim-braquiária neste consórcio foi de $68,13 \%$, fazendo com que a média ponderada deste tratamento superasse à da gramínea adubada com nitrogênio.

Tanto os teores de fósforo quanto os de potássio, cálcio e magnésio na época chuvosa, no consórcio capimbraquiária com o estilosantes, não diferiram $(\mathrm{P}>0,05)$ dos determinados no capim-braquiária adubado com nitrogênio (Tabela 6). Embora as leguminosas, em geral, apresentem teores de cálcio e magnésio superiores aos das gramíneas, a participação do estilosantes no consórcio foi pequena

Tabela 6 - Concentrações (dag/kg) de minerais na matéria seca (MS) de gramíneas avaliadas com capim-braquiária adubado com nitrogênio nas épocas seca e chuvosa

\begin{tabular}{|c|c|c|c|c|c|c|c|c|}
\hline & \multicolumn{4}{|c|}{ Capim-braquiária } & \multicolumn{4}{|c|}{ Capim-gordura } \\
\hline & $\mathrm{Ca}$ & $\mathrm{Mg}$ & $\mathrm{P}$ & $\mathrm{K}$ & $\mathrm{Ca}$ & $\mathrm{Mg}$ & $\mathrm{P}$ & $\mathrm{K}$ \\
\hline \multicolumn{9}{|l|}{ Época seca } \\
\hline$B+E^{1}$ & $0,598 \mathrm{a}$ & $0,169 b$ & $0,170 \mathrm{~b}$ & $1,445 b$ & $0,414 \mathrm{~b}$ & $0,124 \mathrm{a}$ & $0,268 b$ & $1,215 b$ \\
\hline $\mathrm{B}+0 \mathrm{~N}^{2}$ & $0,573 a$ & $0,228 b$ & $0,166 b$ & $1,233 a$ & $0,405 b$ & $0,149 a$ & $0,123 a$ & $0,821 \mathrm{a}$ \\
\hline$B+50 N$ & $0,548 a$ & $0,255 a$ & $0,130 \mathrm{a}$ & $1,153 \mathrm{a}$ & $0,386 b$ & $0,152 \mathrm{a}$ & $0,165 a$ & $1,246 b$ \\
\hline $\mathrm{B}+100 \mathrm{~N}$ & $0,481 \mathrm{a}$ & $0,279 a$ & $0,138 b$ & $0,840 a$ & $0,298 \mathrm{a}$ & $0,154 \mathrm{a}$ & $0,198 \mathrm{a}$ & $1,247 b$ \\
\hline $\mathrm{B}+150 \mathrm{~N}$ & $0,498 \mathrm{a}$ & $0,267 a$ & $0,147 b$ & $0,781 \mathrm{a}$ & $0,280 \mathrm{a}$ & $0,148 \mathrm{a}$ & $0,213 \mathrm{a}$ & $1,143 b$ \\
\hline $\mathrm{CV}^{3}(\%)$ & 12,20 & 13,57 & 12,86 & $1,445 b$ & 13,49 & 13,58 & 10,32 & 5,11 \\
\hline \multicolumn{9}{|c|}{ Época chuvosa } \\
\hline$B+E^{1}$ & $0,592 \mathrm{a}$ & $0,148 \mathrm{a}$ & $0,238 \mathrm{a}$ & $1,867 \mathrm{a}$ & - & - & - & - \\
\hline $\mathrm{B}+0 \mathrm{~N}^{2}$ & $0,427 \mathrm{a}$ & $0,105 a$ & $0,248 a$ & 2,053a & - & - & - & - \\
\hline $\mathrm{B}+50 \mathrm{~N}$ & $0,502 \mathrm{a}$ & $0,124 a$ & $0,231 \mathrm{a}$ & $1,904 a$ & - & - & - & - \\
\hline $\mathrm{B}+100 \mathrm{~N}$ & $0,523 a$ & $0,129 a$ & $0,221 \mathrm{a}$ & $1,557 \mathrm{a}$ & - & - & - & - \\
\hline $\mathrm{B}+150 \mathrm{~N}$ & $0,504 \mathrm{a}$ & $0,124 \mathrm{a}$ & $0,238 \mathrm{a}$ & 1,693a & - & - & - & - \\
\hline $\mathrm{CV}^{3}(\%)$ & 13,82 & 52,12 & 14,27 & 13,60 & - & - & - & - \\
\hline
\end{tabular}

${ }^{1} \mathrm{~B}+\mathrm{E}-$ capim-braquiária e estilosantes em consórcio.

$2 \mathrm{~N}$ - nitrogênio $(\mathrm{kg} / \mathrm{ha})$.

$3 \mathrm{CV}$ - coeficiente de variação.

Médias das doses de $\mathrm{N}$ seguidas pela mesma letra da média do consórcio, na coluna, não diferem $(P>0,05)$ entre si pelo teste de Dunnett. 
(30,09\% da MS total), o que explica a ausência de alteração nos teores de cálcio e magnésio entre os consórcios e as doses de nitrogênio avaliadas.

\section{Conclusões}

O capim-braquiária apresenta elevada produção de matéria seca, adequada cobertura do solo e boa composição química, tanto no período seco como no chuvoso, em todas as doses de nitrogênio avaliadas, portanto, constitui boa alternativa para renovação de pastagens degradadas. O consórcio de capim-braquiária com o estilosantes pode substituir a adubação nitrogenada até a dose de nitrogênio de $100 \mathrm{~kg} / \mathrm{ha}$ e pode ser uma alternativa para reduzir os custos de produção.

\section{Literatura Citada}

ALVES, S.J.; MEDEIROS, G.B. Leguminosas em renovação de pastagens. In: SIMPÓSIO SOBRE ECOSSISTEMA DE PASTAGENS, 3., 1997, Jaboticabal. Anais... Jaboticabal: Universidade Estadual Paulista, 1997. p.251-272.

ALVIN, M.J.; RESENDE, H.; BOTREL, M.A. Efeito da freqüência de cortes e do nível de nitrogênio sobre a produção e qualidade da matéria seca do "coastcross". In: WORKSHOP SOBRE O POTENCIAL FORRAGEIRO DO GÊNERO CYNODON, 1996, Juiz de Fora. Anais... Juiz de Fora: EMBRAPA-CNPGL, 1996. p. 45-55.

ANDRADE, A.C.; FONSECA, D.M.; QUEIROZ, D.S. et al. Adubação nitrogenada e potássica em capim-elefante (Pennisetum purpureum Schum, cv. Napier). Ciência Agrotécnica, edição especial, p.1643-51, 2003.

BARCELlOS, A.O.; ANDRADE, R.P.; KARIA, C.T. et al. Potencial e uso de leguminosas forrageiras dos gêneros Stylosanthes, Arachis e Leucaena. In: SIMPÓSIO SOBRE MANEJO DA PASTAGEM, 17., Piracicaba. Anais... Piracicaba: Fundação de Estudos Agrários Luiz de Queiroz, 2000. p.297-357.

BOTREL, M.A.; ALVIM, M.J.; XAVIER, D.F. et al. Avaliação de forrageiras em dois municípios do Campo das Vertentes de Minas Gerais. Revista da Sociedade Brasileira de Zootecnia, v.23, n.2, p.189-96, 1994.

BOTREL, M.A.; XAVIER, D.F. Forrageiras para áreas de relevo acidentado. In: CARVALHO, M.M.; ALVIM, M.J. (Eds.). Pastagens para gado de leite em regiões de influência da Mata Atlântica. Juiz de Fora: Embrapa Gado de Leite (EMBRAPA/CNPGL), 2000. p.25-40.

CADISH, G.; SILVESTER-BRADLEY, R.; NOSBERGER, J. ${ }^{15} \mathrm{~N}$ - based estimation of nitrogen fixation by eight tropical forage legumes at two levels of P:K supply. Field Crops Research, v.22, p.181-94, 1989.

CANTARUTTI, R.B.; BODDEY, R.M. Transferência de nitrogênio das leguminosas para as gramíneas. In: SIMPÓSIO INTERNACIONAL SOBRE PRODUÇÃO ANIMAL EM PASTEJO, 1997, Viçosa, MG. Anais... Viçosa, MG: Universidade Federal de Viçosa, 1997. p.431-45.
CARVALHO, M.M.; SARAIVA, O.F. Resposta do capim-gordura (Melinis minutiflora Beauv.) a aplicações de nitrogênio em regime de corte. Revista da Sociedade Brasileira de Zootecnia, v.16, n.5, p.442-54, 1987.

COSTA, N.L.; SAIBRO, J.C. Adubação nitrogenada, época e alturas de cortes em Paspalum guenoarum Arech. Agronomia Sulriograndense, v.20, n.1, p.33-49, 1984.

CRUZ FILHO, A.B.; CÓSER, A.C.; NOVELLY, P.E. Comparação entre métodos de plantio de $B$. decumbens em pastagens de capim-gordura em áreas montanhosas. Revista da Sociedade Brasileira de Zootecnia, v.15, n.4, p.297-306, 1986.

FAVORETTO, V.; REIS, R.A.; VIEIRA, P.F. et al. Efeito da adubação nitrogenada ou de leguminosas no ganho de peso vivo de bovinos em pastagens de capim-colonião. Pesquisa Agropecuária Brasileira, v.20, n.4, p.467-74, 1985.

GOMIDE, J.A.; COSTA, G.G.; SILVA, M.A.M.M. et al. Adubação nitrogenada e consorciação do capim-colonião e capim-jaraguá com leguminosas. I. Produtividade e teor de nitrogênio das gramíneas e das misturas. Revista da Sociedade Brasileira de Zootecnia, v.13, n.1, p.11-21, 1984.

JARVIS, S.C. Nitrogen management and sustainability. In: CHERNEY, J.H., CHERNEY, D.J.R. (Eds.) Grass for dairy cattle. Wallingford: CAB Internacional, 1998. p.161-192.

KÖEPEN, W. Climatologia. Buenos Aires: Gráfica Panamericana, 1948. 478p.

MANNETJE, L.T.; HAYDOCK, K.P. The dry-weight-rank method for the botanical analysis of pasture Journal British Grassland Science, v.18, n.4, p.268-275, 1963.

MENDES, L.A. Efeito de doses de nitrogênio em gramíneas do gênero Cynodon. Lavras: Universidade Federal de Lavras, 2000. 55p. Dissertação (Mestrado em Zootecnia) - Universidade Federal de Lavras, 2000.

MOREIRA, L.M. Rendimento e composição químicobromatológica de forrageiras tropicais introduzidas em pastagens de capim-gordura (Melinis minutiflora Beauv.) degradada. Viçosa, MG: Universidade Federal de Viçosa, 2000. 121p. Dissertação (Mestrado em Zootecnia) - Universidade Federal de Viçosa, 2000.

MORRISON, J. Effects of nitrogen fertilizer. In: SNAYDON, R.W. (Ed.) Ecossystems of the word 17B - Managed Grasslands, Analytical Studies. Amsterdam: Elsevier, 1987. p.61-70.

PACIULLO, D.S.C.; GOMIDE, J.A.; GUIMARÃES, K.R. Adubação nitrogenada do capim-elefante cv. Mott. I. Rendimento forrageiro e características morfofisiológicas ao atingir 80 e $120 \mathrm{~cm}$ de altura Revista Brasileira de Zootecnia, v.27, n.6, p.1069-1075, 1998.

PEREIRA, J.M. Produção e persistência de leguminosas em pastagens tropicais. In: SIMPÓSIO DE FORRAGICULTURA E PASTAGENS, 2., 2001, Lavras. Anais. Lavras: Universidade Federal de Lavras, 2001. p.111-142.

RIBEIRO, K.G.; GOMIDE, J.A.; PACIULLO, D.S.C. Adubação nitrogenada do capim-elefante cv. Mott. 2. Valor nutritivo ao atingir 80 e $120 \mathrm{~cm}$ de altura. Revista Brasileira de Zootecnia, v.28, n.6, p.1213-20, 1999.

RODRIGUES, L.R.A.; REIS, R.A. Estabelecimento de outras forrageias em áreas de Brachiaria spp. In: SIMPÓSIO SOBRE MANEJO DA PASTAGEM, 11., 1994, Piracicaba. Anais... Piracicaba: Fundação de Estudos Agrários Luiz de Queiroz, 1994. p.299-325.

SILVA, D.J. Análise de alimentos (métodos químicos e biológicos). 2.ed. Viçosa, MG: Universidade Federal de Viçosa, 165p, 1990.

Van SOEST, P.J. Symposium on factors influencing the voluntary intake of herbage by ruminants: voluntary intake relation to chemical composition and digestibility. Journal of Animal Science, v.24, n.3, p.834-44, 1965. 